\title{
PROBLEMATYKA PODMIOTOWOŚCI PRAWNEJ ZWIERZĄT NA PRZYKŁADZIE KONCEPCJI UTYLITARYZMU PETERA SINGERA
}

\section{THE ISSUE OF ANIMAL LEGAL PERSONALITY ILLUSTRATED BY THE EXAMPLE OF PETER SINGER'S CONCEPT OF UTILITARIANISM}

\section{STRESZCZENIE}

Przedmiotem artykułu jest analiza koncepcji upodmiotowienia zwierząt Petera Singera. Jakkolwiek jest to koncepcja etyczna, to jednak niektórzy przedstawiciele doktryny powołują się na nią i dowodzą, że we współczesnym świecie upodmiotowienie zwierząt jest już koniecznością. Koncepcja P. Singera opiera się na utylitaryzmie preferencji, choć odwołuje się również do utylitaryzmu klasycznego.

\footnotetext{
" Magister administracji, Orange Polska S.A.
} 
Zwolennicy Singera bardzo zdecydowanie krytykują aktualnie obowiązujący model prawnej ochrony zwierząt. Okazuje się jednak, że przywołując źródła prawnej ochrony zwierząt oraz źródła ochrony praw człowieka, odkrywamy ich ponadczasową wartość, która wynika z właściwego rozpoznania natury zwierząt i człowieka jako osoby. Natomiast analiza koncepcji upodmiotowienia zwierząt, którą prezentują P. Singer i jego zwolennicy, prowadzi do wniosku, że opiera się ona na błędach poznawczych, dotyczących przede wszystkim natury człowieka. W konsekwencji, koncepcja P. Singera nie tylko nie daje gwarancji lepszej ochrony zwierząt, ale jest także zagrożeniem dla ochrony praw człowieka.

\section{Słowa kluczowe}

Upodmiotowienie zwierząt; Peter Singer; prawna ochrona zwierząt; ochrona praw człowieka; osoba; utylitaryzm.

\section{ABSTRACT}

The purpose of this article is the analysis of Peter Singer's concept of animal legal personality. Although it is an ethical idea, some doctrine representatives refer to it and prove that legal personality of animals is a necessity. Peter Singer's concept is based on the utilitarianism of preferences although it also refers to classical utilitarianism. His followers strongly criticize the current model of animal legal protection. It turns out, however, that the foundation of animal and human being protection is timeless and must be based on animals nature and a human being as a person. Whereas, the analysis of Peter Singer's concept leads to the conclusion that it is based on cognitive mistakes, concerning mostly human nature. In consequence, Peter Singer's concept of utilitarianism not only does not help better animal protection, but is also a threat to human rights protection.

\section{Keywords}

Animal empowerment; Peter Singer; legal protection of animals; protection of human rights; person; utilitarianism. 
Każda osoba, która posiada zwierzę domowe i zgodziła się nim opiekować, jest odpowiedzialna za jego zdrowie i dobro.

Art. 4 ust. 1

Europejskiej konwencji ochrony zwierząt domowych

\section{WPROWADZENIE}

Ochrona zwierząt jest we współczesnym świecie pełna paradoksów. Z jednej strony sytuacje niehumanitarnego przechowywania zwierząt hodowlanych, walki z udziałem byków, wiwisekcje. Z drugiej strony konkursy piękności zwierząt czy dieta wegańska, która odrzuca jakąkolwiek żywność pochodzenia zwierzęcego. To tylko niektóre przykłady, świadczące o bardzo zróżnicowanej postawie człowieka wobec zwierząt.

W ramach polskiego porządku prawnego, kwestię prawnej ochrony zwierząt reguluje ustawa z dnia 21 sierpnia $1997 \mathrm{r}$. o ochronie zwierząt ${ }^{1}$. Niewątpliwie, w relacji człowiek a zwierzę, przedmiotowa ustawa ma charakter antropocentryczny. W ostatnich latach coraz głośniej mówi się o propozycji, która może zmienić nie tylko podstawy prawej ochrony zwierząt, ale być może także całego systemu prawa. Chodzi mianowicie o koncepcje, które głoszą nie-antropocentryczną wizję świata ${ }^{2}$, a w ślad za tym również prawa. Głoszą, że antropocentryzm doprowadził do ogromnego zniszczenia środowiska oraz hekatomby zwierząt. Propozycje nie-antropocentryczne, pomimo ich różnorodności, odrzucają centralne miejsce człowieka w świe-

1 Tj. Dz.U. z 2003 r. Nr 106, poz. 1002 ze zmianami - dalej jako ustawa o ochronie zwierząt.

2 Przegląd stanowisk nie-antropocentrycznych: Z. Piątek Etyka środowiskowa. Nowe spojrzenie na miejsce człowieka w przyrodzie, Kraków 1998 oraz A. Pawłowski Odpowiedzialność człowieka za przyrodę. Humanizm ekologiczny, vol.5, Lublin 1999. 
cie i wskazują, że człowiek stanowi tylko jeden z równorzędnych elementów środowiska.

Na kanwie tych propozycji, pojawiły się także nowe projekty zmiany prawa. Należy do nich przede wszystkim propozycja upodmiotowienia zwierząt, którą w polskiej doktrynie reprezentują: J. Białocerkiewicz, Ł. Smaga i T. Pietrzykowski. Podnoszą oni, że przepisy prawa ochrony środowiska są już niewystarczające dla skutecznej ochrony zwierząt ${ }^{3}$. W swoich analizach odwołują się między innymi do jednego z najbardziej znanych zwolenników upodmiotowienia zwierząt, australijskiego filozofa i etyka Petera Singera ${ }^{4}$.

Na dzień dzisiejszy nie przedstawiono jeszcze konkretnej inicjatywy ustawodawczej. Póki co jest to propozycja dyskutowana, choć trzeba zaznaczyć, że coraz bardziej stanowczo i pojawienie się propozycji legislacyjnej jest tylko kwestią czasu. Już na wstępie należy zaznaczyć, że argumenty za upodmiotowieniem zwierząt często nie mają charakteru prawnego, ale raczej filozoficzny, etyczny, biologiczny czy biosocjologiczny. Ich analiza prowadzi do pytania, na ile upodmiotowienie zwierząt jest problemem prawnym, poza samym faktem wprowadzenia takiego rozwiązania. W konsekwencji, na ile ustawodawca, a także przedstawiciele doktryny, są w stanie prowadzić rzetelny dyskurs i jakie powinny być kryteria oceny tych propozycji. Analiza tych propozycji prowadzi do konkluzji, że przy ocenie propozycji upodmiotowienia zwierząt, duże znaczenie ma odpowiedź na pytanie, kim jest człowiek i jakie jest jego miejsce w świecie. Wyjaśnienie tej kwestii wymaga odwołania się do filozoficznej kategorii osoby. Oczywiście nie sposób objąć całego bogactwa tej problematyki, dlatego też $\mathrm{w}$ tym artykule przeprowadzono analizę propozycji P. Singera, na którego powołują się wyżej wymienieni przedstawiciele teorii i filozofii prawa.

3 Podstawowa literatura tych autorów w zakresie praw zwierząt to: J. Białocerkiewicz, Status prawny zwierzat. Prawa zwierząt czy prawna ochrona zwierząt, Torun 2005; Ł. Smaga, Ochrona humanitarna zwierząt, Białystok 2010; T. Pietrzykowski, Spór o prawa zwierząt, Katowice 2007.

4 Na P. Singera powołują się także autorzy monografii Status zwierzęcia. Zagadnienia filozoficzne i prawne, (red.) T. Gardocka, A. Gruszczyńska, Toruń 2012. 
Początek rozważań to spojrzenie na źródła prawnej ochrony zwierząt z punktu widzenia ustawy o ochronie zwierząt. Właśnie taką ochronę zwierząt kwestionują J. Białocerkiewicz, Ł. Smaga i T. Pietrzykowski. W związku z tym, rozdział drugi artykułu jest przypomnieniem źródeł ochrony praw człowieka i prawnej ochrony zwierząt. Okazuje się jednak, że wymienieni autorzy, powołując się między innymi na P. Singera, odrzucają podstawy tej ochrony, a należy do nich przede wszystkim godność człowieka-osoby jako źródła praw człowieka. Aby podjąć próbę dyskusji z propozycjami P. Singera, konieczne będzie ich krótkie przedstawienie, dlatego rozdział trzeci artykułu jest krótką prezentacją założeń etyki utylitarystycznej P. Singera, przede wszystkim w zakresie źródeł tej etyki, a także jej stanowiska dotyczącego osoby. Rozdział czwarty artykułu to ocena tych propozycji z punktu widzenia samej filozofii. Nie będą to badania stricte filozoficzne, ale spojrzenie na propozycje P. Singera z punktu widzenia dorobku filozoficznego odnoszącego się do człowieka-osoby. Wnioski płynące z tych porównań, będą podstawą do dokonania oceny propozycji upodmiotowienia zwierząt P. Singera z punktu widzenia prawa.

\section{PRAWNA OCHRONA ZWIERZĄT}

Zanim kwestia upodmiotowienia zwierząt zostanie podjęta wprost, konieczne jest najpierw krótkie przedstawienie źródeł prawnej ochrony zwierząt w ustawie o ochronie zwierząt. Zgodnie z art. 5 ustawy o ochronie zwierząt „Każde zwierzę wymaga humanitarnego traktowania". Jak wskazuje W. Radecki „Pojęcie humanitarnego traktowania jest pojęciem prawnym, zdefiniowanym w art. 4 pkt 2 jako traktowanie uwzględniające potrzeby zwierzęcia oraz zapewniające mu opiekę i ochronę"5 i dalej wyjaśnia, że „adresatem normy zawartej w art. 5 jest przede wszystkim ten, kto z jakiegokolwiek tytułu (własność, s. 63.

5 W. Radecki, Ustawa o ochronie zwierząt. Komentarz, Warszawa 2012, 
posiadanie, dzierżenie) ma styczność ze zwierzęciem. Jeżeli chodzi o inne osoby, to wymóg humanitarnego traktowania sprowadza się do powstrzymania się od zachowań niehumanitarnych" ". Pojęcie humanitarnego traktowania nie określa precyzyjnie jak należy postępować. Wojciech Radecki zaznacza, że przy ocenie humanitarnego traktowania zwierząt trzeba sięgnąć do praktyki normalnych ludzi, a nie ludzi przeczulonych na punkcie stosunku do zwierząt. Jednym ze znaczeń słowa „humanitarny” jest: „polegający na dobrym traktowaniu, oszczędzaniu cierpień" ". Wynika stąd, że traktowanie zwierząt w sposób humanitarny oznacza, że należy traktować je dobrze i starać się nie wyrządzać im krzywdy. Jest to odwołanie się do podstawowej zasady prawa naturalnego, którą znano już w starożytności, a później potwierdził ją św. Tomasz z Akwinu - „dobro należy czynić i dążyć doń, a zła należy unikać"s. W związku z tym, że prawo tworzy nieprzekraczalne granice zachowań, art. 6 ustawy o ochronie zwierząt zawiera cały katalog zachowań, które można uznać za niehumanitarne. Zabijanie zwierząt jest dozwolone tyko w określonych przypadkach, natomiast całkowicie zabronione jest znęcanie się nad zwierzętami. Zatem ustawa o ochronie zwierząt wyraźnie określa, jakie zachowania są zabronione (co jest złem), ale nie określa dokładnie, jakie zachowania są pożądane (co jest dobrem). Człowiek humanitarny nie przekroczy granic wyznaczonych przez prawo, a jego pozytywny stosunek do zwierząt będzie zależny od konkretnych sytuacji i jego indywidualnych decyzji.

Zaprezentowane powyżej źródła prawnej ochrony zwierząt, można rozszerzyć również na całą humanitarną ochronę zwierzą ${ }^{9}$, w tym także prawodawstwo Unii Europejskiej. Motto tego artykułu jest właśnie wskazaniem na fakt, że człowiek jako

6 Ibidem s. 63.

7 Wielki słownik języka polskiego, (red.) B. Dunaj, Warszawa 2009, s. 178.

8 Św. Tomasz z Akwinu, Suma teologiczna, t. 13, artykuł 2, źródło: http://www.katedra.uksw.edu.pl/suma/suma_indeks.htm.

9 Zgodnie z podziałem wprowadzonym przez L. Jastrzębskiego, który dzieli ochronę zwierząt na ochronę zachowawczą i kształtowaną, a w ramach kształtowanej ochronę humanitarna i użytkową. L. Jastrzębski, Prawo ochrony środowiska w Polsce, Warszawa 1990, s. 106 i nast. 
istota moralna ma powinność (może podjąć odpowiedzialność za swoje czyny) zachowywać się w sposób uwzględniający dobro zwierzęcia - człowiek jest zdolny zrezygnować z własnych przyjemności czy korzyści na rzecz innej istoty.

Taki sposób prawnej ochrony zwierząt bywa przez niektórych kontestowany. W polskiej literaturze prawniczej pojawiają się głosy o konieczności przyznania podmiotowości prawnej zwierzętom, która ma być lekarstwem na ich nieludzkie traktowanie, a dokładniej należałoby powiedzieć na łamanie prawa w tym zakresie ${ }^{10}$. Dokładniejsza analiza tych argumentów zostanie podjęta w dalszej części artykułu. W tej części można zapytać, niejako wstępnie, czy system prawny taką możliwość dopuszcza. Perspektywa całego systemu prawa sugeruje, że zagadnienie upodmiotowienia zwierząt wykracza poza prawo ochrony środowiska. Przyjmuję tutaj za W. Radeckim, że przepisy ustawy o ochronie zwierząt stanowią fragment większej całości obejmowanej zwykle mianem prawa o ochronie przyrody, które z kolei wchodzi w zakres prawa ochrony środowiska ${ }^{11}$. Jednak uwzględnienie w całości prawa ochrony środowiska niczego tutaj nie zmienia, ponieważ nie można nadać zwierzętom podmiotowości prawnej tylko w ramach jednej dziedziny prawa. Konsekwencje takiego rozwiązania rozciągałyby się na cały system prawa.

W aktualnym stanie prawnym podmiotowość prawna dotyczy tylko człowieka. „Najogólniej rzecz ujmując, gdy mówi się o »prawie podmiotowym«, ma się na myśli jakąś pozytywnie ocenianą (korzystną) sytuację jednostki w społeczeństwie"12. Definicja zaproponowana przez Z. Radwańskiego, wskazuje na bardzo ważną kwestię - o podmiotowości prawnej można mówić w odniesieniu do społeczeństwa, a prawo jest częścią nauk społecznych.

10 Pojawiające się filmy, które pokazują nieludzkie traktowanie zwierząt nie są dowodem na dowolne traktowanie zwierząt i słabość systemu prawa, ale przede wszystkim są przykładem zachowań karalnych a nierzadko patologicznych, które kwalifikują się do leczenia psychiatrycznego.

11 W. Radecki, Ustawa o ochronie zwierząt, s. 24.

12 Z. Radwański, Prawo cywilne - część ogólna, Warszawa 2009, s. 83. 
Powstaje zatem pytanie, czy nauki społeczne powinny się zajmować problematyką upodmiotowienia zwierząt, skoro zwierzęta nie są częścią społeczeństwa. Jeśli zachodzi taka konieczność, to przedmiotowy problem może wykraczać nie tylko poza prawo ochrony środowiska, ale w ogóle poza naukę prawa, a może nawet poza nauki społeczne. W związku z tym, że zwierzę nie jest dla człowieka partnerem w pełnym tego słowa znaczeniu, dlatego rozważania dotyczące ich statusu prawnego wydają się tym samym bezprzedmiotowe. Jednak jak wskazywał Z. Ziembiński: „Spory dotyczące określania charakteru podmiotów społecznych nie będących ludźmi sprowadzają się $\mathrm{w}$ istocie do różnego sposobu pojęciowego ujmowania zjawisk, w których występują ludzie w pewnych rolach wyznaczanych im przez odpowiedniego rodzaju wzory kulturowe"13. Z. Ziembiński odwoływał się tutaj do H. Kelsena: „Jest np. pewien element trafności w zaskakującej, zdawałoby się, konstrukcji myślowej $\mathrm{H}$. Kelsena, według której podmiotem w świetle prawa jest wszystko to, co »prawo«, a więc pewien szczególny zbór reguł kulturowych ujętych w systemie prawnym, za podmiot tego rodzaju uważa"14. Z. Ziembiński sugeruje za Kelsenem, że członek społeczeństwa nie musi być określony biologicznie, ale jest to według niego kwestia umowy, a więc członkiem społeczeństwa może być wszystko to, co za takie zostanie uznane. $\mathrm{W}$ tym świetle nadanie zwierzętom podmiotowości prawnej byłoby w zasadzie dopuszczalne, co prawda umownie, ale mimo wszystko dopuszczalne. Czy istotnie jest to kwestia umowy? Konieczne jest w tym miejscu odwołanie się do źródeł prawnej ochrony zwierząt i źródeł ochrony praw człowieka.

13 Z. Ziembiński, Podstawowe problemy prawoznawstwa, Warszawa 1980, s. 316.

14 Ibidem, s. 316. 


\section{3. ŹRÓDŁA PRAWNEJ OCHRONY ZWIERZĄT ORAZ OCHRONY PRAW CZEOWIEKA}

Szczególny rozwój w zakresie prawnej ochrony zwierząt oraz ochrony praw człowieka przypada na wiek XX. Dotyczy to przede wszystkim ochrony powszechnej i, co istotne w praktyce, instytucjonalnej. Jednak, paradoksalnie, to właśnie XX w. charakteryzuje się wykorzystywaniem zwierząt na skalę masową, a także hekatombą dwóch wojen światowych oraz występującym w wielu miejscach świata, zbrodniom przeciwko ludzkości. Celem tego rozdziału jest zarysowanie prawnej ochrony zwierząt oraz ochrony praw człowieka i wskazanie na źródła tej ochrony.

Pierwszy polski akt prawny dotyczący humanitarnej ochrony zwierząt, to rozporządzenie Prezydenta Rzeczypospolitej z 22 marca 1928 r. o ochronie zwierzą ${ }^{15}$. Jak przypomina W. Radecki, należy również pamiętać o średniowiecznym tzw. regale panującego: „regale łowieckie, tj. zastrzeżenie polowania tylko dla panującego lub osób obdarzonych przez niego specjalnym przywilejem, obiektywnie ograniczało niekontrolowane pozyskiwanie grubego zwierza, aczkolwiek o świadomej ochronie przyrody nie można jeszcze mówić"16. Niewątpliwie, prawna ochrona zwierząt była ściśle związana z ochroną przyrody. Zdaniem tego autora „o ochronie przyrody jako liczącym się ruchu społecznym, przybierającym także wyraźne formy prawne, można mówić w odniesieniu do ziem polskich w drugiej połowie XIX w."17. Zatem, mówiąc o prawnej ochronie zwierząt w Polsce w jej współczesnym rozumieniu, które rozpoczyna się rozporządzeniem o ochronie zwierząt, nie można zapominać o historycznych korzeniach tej ochrony. Była to ochrona bardzo

15 Tj. Dz.U. z 1932 r. Nr 42, poz. 417 ze zmianami, dalej jako rozporządzenie o ochronie zwierząt.

16 W. Radecki, Ustawa o ochronie przyrody. Komentarz, Warszawa 2012, s. 18.

17 W. Radecki, Ochrona walorów turystycznych $w$ prawie polskim, Warszawa 2011, s. 43. 
niedoskonała, ale nie jest to powód do jej całkowitego odrzucenia.

W aktualnie obowiązującym stanie prawnym, zwierzęta objęte są ochroną na skalę wcześniej niespotykaną. Składają się na nią przede wszystkim przepisy obowiązujące w poszczególnych krajach, włącznie z systemem ochrony instytucjonalnej (oczywiście można kwestionować, czy system ten jest w pełni sprawny), a w państwach należących do Unii Europejskiej całego unijnego systemu prawa. Należy również uwzględnić Światową Deklarację Praw Zwierząt. Jakkolwiek nie jest ona dokumentem wiążącym państwa, a sposób jej wprowadzenia może budzić wątpliwości ${ }^{18}$, to jednak można ją potraktować jako ważny głos w sprawie prawnej ochrony zwierząt czy też swego rodzaju punkt odniesienia dla prawodawców krajowych.

W ramach polskiego porządku prawnego, istotę prawnej ochrony zwierząt wyraża art. 1 ustawy o ochronie zwierząt, który stanowi: „Zwierzę, jako istota żyjąca, zdolna do odczuwania cierpienia, nie jest rzeczą. Człowiek jest mu winien poszanowanie, ochronę i opiekę". Prawna ochrona zwierząt w Polsce wynika zatem z faktu, który został dostrzeżony przez człowieka, że po pierwsze. zwierzę jest istotą żyjącą, a po drugie, że jest to istota zdolna do odczuwania cierpienia.

W ramach unijnego porządku prawnego, można przywołać przede wszystkim art. 13 Traktatu o funkcjonowaniu Unii Europejskiej ${ }^{19}$, który stanowi: „Przy formułowaniu i wykonywaniu polityki rolnej, rybołówstwa i transportu Unii oraz jej polityk dotyczących rynku wewnętrznego, badań i rozwoju technologicznego oraz przestrzeni kosmicznej, Unia i Państwa Członkowskie w pełni uwzględniają wymagania w zakresie dobrostanu zwierząt jako istot zdolnych do odczuwania, przy równoczesnym przestrzeganiu przepisów prawnych i administracyjnych oraz zwyczajów Państw Członkowskich związanych w szczególności z obyczajami religijnymi, tradycjami kulturowymi i dziedzictwem regionalnym". Obowiązuje również szereg

18 W. Radecki, Ustawa o ochronie zwierząt, s. 37.

19 Wersja skonsolidowana Dz.Urz. UE C 326/01 z 26.10.2012 r. ze zm. 
aktów prawnych, które dotyczą konkretnych spraw ${ }^{20}$. Generalnie, można powiedzieć, że źródłem prawnej ochrony zwierząt w ramach Unii Europejskiej jest, analogicznie jak w polskim porządku prawnym, zwrócenie uwagi na fakt, że zwierzęta są istotami zdolnymi do odczuwania cierpienia i w związku z tym wymagają takiego traktowania, które ten fakt uwzględnia.

Nie można również zapominać, że prawna ochrona zwierząt jest częścią prawa ochrony środowiska. W związku z tym, ich ochrona jest niejako wzmacniana przez filozofię tego prawa. W jego podstawowych założeniach, tak środowisko jak i jego poszczególne elementy, posiadają wartość ponadczasową i właśnie z tego względu należy objąć je ochroną (m.in. ochrona gatunkowa).

Inaczej przedstawia się ochrona praw człowieka. Począwszy od ochrony międzynarodowej, poprzez ochronę na poziomie poszczególnych kontynentów czy organizacji międzynarodowych, aż po ochronę w ramach krajowych porządków prawnych. Tak uniwersalny porządek ochrony praw człowieka nie ma jednak długiej historii. Podkreśla się, że „przez wiele wieków prawo określało przywileje, uprawnienia i obowiązki poszczególnych grup społecznych, stanów itp. Wypływające z niego prawa jednostki nie były jej prawami podmiotowymi, ale przysługiwały jej jako członkowi danej grupy społecznej”21. Były to przede wszystkim prawa nadane, ale także, co równie istotne, prawa nadane tylko określonej grupie społecznej. Jak słusznie zauważa B. Banaszak: „Deklaracja Praw Człowieka i Obywatela, Deklaracja Niepodległości Stanów Zjednoczonych, stanowe ustawy amerykańskie i Konstytucja federalna różniły się zasadniczo od wszystkich wcześniejszych regulacji praw jednostki. Były one aktami, w których po raz pierwszy w historii uznano

20 Przykładowo: Europejska Konwencja w sprawie ochrony zwierząt kręgowych wykorzystywanych do celów doświadczalnych i innych celów naukowych, rozporządzenie Komisji (WE) nr 1771/94 z dnia 19 lipca 1994 r. ustanawiające przepisy dotyczące wprowadzania do Wspólnoty skór i towarów wytwarzanych z niektórych gatunków dzikich zwierząt, rozporządzenie Rady (WE) nr 1099/2009 z dnia 24 września 2009 r. w sprawie ochrony zwierząt podczas ich uśmiercania i in.

21 B. Banaszak, Prawo konstytucyjne, Warszawa 2010, s. 460. 
prawa każdej jednostki i prawnie je zagwarantowano. Wyrażały zasadę, iż prawa człowieka przysługują każdej osobie. Prawa te oraz prawa obywatelskie traktowano jako niezbywalne, tzn. takie, których państwo nie może jednostki pozbawić, ani też sama jednostka nie może się ich zrzec"22. Następuje zatem odwrócenie relacji. To nie państwo, w akcie łaski, nadaje człowiekowi te podstawowe prawa, ale przysługują one człowiekowi, już tylko z samego faktu bycia człowiekiem. W ocenie S. Wronkowskiej „Wolności obywatelskie (tzw. prawa wolnościowe) sprowadzają się bowiem do zakazu ingerencji organów państwa w pewne sfery zachowań obywateli i - zazwyczaj - do obowiązku stworzenia przez państwo instytucjonalnych zabezpieczeń powstałej $\mathrm{w}$ ten sposób swobody działania obywateli przed naruszeniem jej ze strony innych"23. Tak rozumiana godność człowieka stanowi zupełnie nową jakość w zakresie praw człowieka.

Powszechna Deklaracja Praw Człowieka uchwalona przez Zgromadzenie Ogólne ONZ dnia 10 grudnia 1948 r. ${ }^{24}$ była efektem porozumienia o zasięgu globalnym. Bolesne doświadczenia kolonializmu, dwóch wojen światowych, zbrodnie przeciw ludzkości były jednym z fundamentów Powszechnej Deklaracji, która już we wstępie przypomina: „Zważywszy że nieposzanowanie i nieprzestrzeganie praw człowieka doprowadziło do aktów barbarzyństwa, które wstrząsnęły sumieniem ludzkości"25. Doświadczenia II wojny światowej pokazują wyraźnie, że prawa człowieka muszą obejmować wszystkich ludzi, ale konieczna jest również silna ochrona instytucjonalna. Międzynarodowa ochrona praw człowieka obejmuje zatem nie tylko prawo materialne, ale również odpowiadające im procedury dochodzenia poszczególnych praw.

Zgodnie z Powszechną Deklaracją źródłem praw człowieka jest jego godność: „Zważywszy, że uznanie przyrodzonej godności oraz równych i niezbywalnych praw wszystkich członków

22 Ibidem, s. 462.

23 S. Wronkowska, Sytuacje wyznaczane przez normy prawne, [w:] S Wronkowska, Z. Ziembiński, Zarys teorii prawa, Poznań 2001, s. 112.

24 Dalej jako Powszechna Deklaracja.

25 Wstęp do Powszechnej Deklaracji. 
wspólnoty ludzkiej jest podstawą wolności, sprawiedliwości i pokoju świata"26. Istotny jest fakt, że ludzkiej godności się nie nadaje, ale jest ona niejako odkryta. Jak trafnie zauważa T. Jasudowicz: „W zasadzie wszystkie dokumenty międzynarodowe unikają w swojej terminologii formuł, które wskazywałyby na kreowanie, tworzenie praw człowieka, lecz - konsekwentnie wskazują na ich uznanie czy potwierdzenie"27. Taka konstrukcja przekłada się na konkretne prawa człowieka. Jak stanowi art. 3 Powszechnej Deklaracji: „Każdy człowiek ma prawo do życia, wolności i bezpieczeństwa swej osoby". Podstawowe prawa człowieka, które były i niestety często są naruszane, zostają w Powszechnej Deklaracji potwierdzone a nie nadane.

Konstytucja Rzeczypospolitej Polskiej z dnia 2 kwietnia $1997 \mathrm{r}^{28}$ uwzględnia taką filozofię praw człowieka. Artykuł 30 Konstytucji RP stanowi: „Przyrodzona i niezbywalna godność człowieka stanowi źródło wolności i praw człowieka i obywatela. Jest ona nienaruszalna, a jej poszanowanie i ochrona jest obowiązkiem władz publicznych". Jak wyraźnie zaznacza M. Piechowiak „do zasadniczych elementów paradygmatycznych koncepcji praw człowieka zaliczyć trzeba twierdzenia o powszechności, przyrodzoności, niezbywalności i równości praw oraz o godności jako źródle praw"29.

Warto również zwrócić uwagę na fakt, że jakkolwiek podstawowe prawa człowieka znalazły swoją realną ochronę dopiero po II wojnie światowej, to jednak ich zaplecze intelektualne wynika z wielowiekowej tradycji, przede wszystkim europejskiej, ale nie tylko. Jak stwierdza W. Osiatyński „powszechna Deklaracja Praw Człowieka była kompromisem i syntezą różnych tradycji, wartości i potrzeb. Większość tych tradycji czerpała z europejskiej myśli społecznej i filozoficznej”30. Tak wyjątkowa

26 Wstęp do Powszechnej Deklaracji.

27 T. Jasudowicz, Konstrukcja normatywna międzynarodowo chronionych praw człowieka, [w:] Prawa człowieka i ich ochrona, praca zbiorowa, Toruń 2010, s. 106.

28 Dz.U. z 1997 r. Nr 78, poz. 483 ze zmianami, dalej jako Konstytucja RP.

29 M. Piechowiak Pojęcie praw człowieka, [w:] Podstawowe prawa jednostki i ich ochrona, [red.] L. Wiśniewski, Warszawa 1997, s. 13.

30 W. Osiatyński, Prawa człowieka i ich granice, Kraków 2011, s. 54. 
zgodność przedstawicieli różnych kultur jest historycznym fenomenem. Co prawda zasadniczym impulsem dla postanowień Powszechnej Deklaracji były bolesne doświadczenia II wojny, to jednak samo jej powstanie nie byłoby możliwe bez tego, co można nazwać dorobkiem tradycji czy kultury. Jak trafnie zauważa K. Wroczyński, „deklaracja zawiera sformułowania wypracowane i uzasadnione już wcześniej, czerpie z wielowiekowej kultury umysłowej, moralnej i prawnej" 31 . W swoich rozważaniach K. Wroczyński odwołuje się do europejskiej szkoły prawa naturalnego: „Wydaje się, że na treściowy zakres praw człowieka większy wpływ wywarły nowożytne szkoły prawa naturalnego, zwłaszcza XVII i XVIII wieku. Filozofowie i prawnicy tworzący tzW. »szkołę prawa naturalnego « usiłowali wywieść »dedukcyjnie« naczelne zasady porządku prawnego (warunku społecznego ładu) i treść podstawowych praw człowieka z abstrakcyjnie pojętej społecznej natury człowieka. Oprócz dowodzenia a priori, które wedle słów H. Grocjusza (założyciela szkoły) jest »samo przez się zrozumiałe i oczywiste prawie w ten sam sposób, jak rzeczy które postrzegamy zmysłami«, dopuszczano dowodzenie a posteriori. Chodzi mianowicie o badanie tego, »co za takie prawo uważają wszystkie narody lub narody bardziej cywilizowane - consensus omniorum. Takie podejście pozwoliło na sformułowanie całego szeregu uprawnień i apriorycznych zasad ładu społecznego i prawnego, a nawet układanie naturalnych praw w katalogi. Zasługi zatem tej szkoły dla sformułowania podstawowych praw ludzkich są niemałe, pomimo dyskusyjnych filozoficznych założeń wyjściowych"32. Można zatem mówić o konkretnym dorobku kultury europejskiej, który jest jednym z fundamentów Powszechnej Deklaracji.

Peter Singer, a za nim wspomniani we wstępie autorzy, próbują udowodnić, że kultura europejska nie jest w stanie poradzić sobie ze współczesnymi problemami (między innymi

31 K. Wroczyński, O źródłach treści praw człowieka, „Człowiek w kulturze”, nr 11, s. 162 .

32 Ibidem, s. 168. 
w zakresie ochrony zwierząt $)^{33}$. Niemniej jednak treści zawarte w Dekalogu, przede wszystkim dotyczące spraw życia i śmierci, zostały podobnie ujęte także $\mathrm{w}$ innych kulturach. Jak przypomina K. Wroczyński „W innych kulturach i religiach, zwłaszcza w tradycji konfucjańskiej, hinduistycznej czy islamskiej, znajdujemy jednak bardzo podobne sformułowania"34. Świadczy to po prostu o tym, że w kwestiach fundamentalnych, jak życie czy wolność od tortur, ludzie nie różnią między sobą.

Już z tego krótkiego wywodu wynika kilka istotnych wniosków. Przede wszystkim należy wskazać, że za normatywnymi zobowiązaniami stoi historia konkretnych, bolesnych doświadczeń, ale towarzyszy im także refleksja. W zakresie ochrony zwierząt jest to stwierdzenie, poniekąd dość oczywiste, że są one istotami odczuwającymi ból i cierpienie, dlatego opieka nad zwierzętami musi ten fakt uwzględniać, a zabijanie zwierząt powinno odbywać bez powodowania zbędnych cierpień. Co więcej, w wielu sytuacjach decyzja o konieczności zabicia zwierząt nie ma charakteru dowolnego. Ochrona gatunków chronionych jest tego najlepszym przykładem. Zatem względy szacunku dla środowiska mogą być przeciwwskazaniem dla zabijania konkretnych gatunków zwierząt.

Inne są źródła ochrony praw człowieka. Przyrodzona godność człowieka jest źródłem nienaruszalności życia człowieka, zakazu tortur, wolności człowieka i in. Ze względu na godność człowieka państwo nie ma prawa łamać wolności i praw człowieka, a także zobowiązane jest czynić wszystko, co zmierza do ich ochrony. Fundamentem praw człowieka jest jego godność. W związku z tym, prawa człowieka dotyczą wszystkich ludzi bez względu na jakiekolwiek różnice. Konsekwentnie, każdy człowiek jest podmiotem prawa, dlatego mówimy o ochronie praw człowieka. Zwierzęta, pomimo bardzo rozbudowanej

33 P. Singer pisze: „Po dwóch tysiącach lat władania naszymi myślami i decyzjami w sprawach życia i śmierci tradycyjna etyka zachodnia załamała się" - P. Singer, O życiu i śmierci. Upadek etyki tradycyjnej, Warszawa 1997, s. 9. Z niektórych tekstów Singera wynika, że prowadzi on osobistą wojnę z kulturą europejską. W takiej sytuacji można mieć wątpliwości, czy badania prowadzone przez Singera są obiektywne.

34 K. Wroczyński, O źródłach treści praw człowieka, s. 163. 
ochrony, nie są podmiotami prawa, dlatego mówimy o prawnej ochronie zwierząt. W świetle powyższych uwag, nie można się także zgodzić z Z. Ziembińskim, że podmiotowość prawna może być kwestią umowy czy pewnych reguł społecznych.

W zakończeniu tego rozdziału, można się również odnieść do skuteczności prawnej ochrony człowieka, czyli w praktyce poszanowania podmiotowości każdego człowieka. Zwolennicy upodmiotowienia zwierząt sugerują, że tylko personifikacja i upodmiotowienie zwierząt może na dzień dzisiejszy przynieść zwierzętom ratunek. Należy tu zatem przypomnieć, że międzynarodowa ochrona praw człowieka nie powstrzymała Czerwonych Khmerów przed ludobójstwem na własnym narodzie, Hutu przed ludobójstwem w Rwandzie, Serbów przed masakrą w Srebrenicy czy Rosjan przed masakrami na Kaukazie. Co warto odnotować, łamanie praw człowieka i niszczenie środowiska często idą ze sobą w parze. Wspomnieć tu można choćby o wojnie w Somali, którą wykorzystywali europejscy przedsiębiorcy, aby składować tam skrajnie szkodliwe odpady ${ }^{35}$. Katastrofa chemiczna w Bhopalu, która miała miejsce w 1984 r., była przyczyną nie tylko zanieczyszczenia środowiska. Od razu po katastrofie śmierć poniosło kilka tysięcy osób, w następnych miesiącach ok. 15 tysięcy, a ok. 100 tysięcy ma do dziś problemy zdrowotne. Właściciel zakładu, przedsiębiorstwo Union Carbide, starał się przede wszystkim uniknąć odpowiedzialności, a jego głównym problemem była minimalizacja strat finansowych ${ }^{36}$. To tylko kilka przykładów, ale celem tego artykułu nie jest epatowanie patologią, której nie uleczy żadne prawo. Wyrażają one jedynie wątpliwości co do skuteczności upodmiotowienia zwierząt i uniknięcia różnego typu patologii, jakich zwierzęta doświadczają ze strony ludzi.

Peter Singer z całą mocą odrzuca jednak antropocentryczny model prawa. Konieczna jest zatem krótka prezentacja jego koncepcji.

35 http://www.politykaglobalna.pl/2012/06/na-krawedzi-ekologicznejkatastrofy-somalia-odpady.

36 http://pl.wikipedia.org/wiki/Katastrofa_w_Bhopalu. 


\section{FUNDAMENT ETYKI UTYLITARYSTYCZNEJ I JEJ KONCEPCJA OSOBY}

Niektórzy wskazują, że aktualnie funkcjonująca prawna ochrona zwierząt jest niewystarczająca, a system ich ochrony nieefektywny. Powołują się na wiele udokumentowanych aktów barbarzyństwa popełnianych na zwierzętach. Wskazują, że taki stan rzeczy musi pociągnąć za sobą odpowiednią reakcję. Jedną z propozycji jest właśnie upodmiotowienie zwierząt. Sam sposób upodmiotowienia zwierząt jest sprawą wtórną ${ }^{37}$.

W polskiej literaturze prawniczej do najbardziej znanych zwolenników tej idei należą: nieżyjący już J. Białocerkiewicz, a także Ł. Smaga i T. Pietrzykowski. W swoich pracach powołują się oni na argumenty, które można potraktować jako szeroko rozumianą filozofię prawa (argumenty etyczne, filozoficzne a także religijne ${ }^{38}$. Wymienieni autorzy, prezentując różne racje, odwołują się między innymi do etyki utylitarystycznej, a także do

37 Może to być np. powstanie nowej kategorii bytów prawnych - podmiotów nieosobowych.

38 Z kwestią powoływania się na argumenty pozaprawne związane są dwa zasadnicze problemy. Po pierwsze czy w ogóle można powoływać się na argumenty, których podstawą nie są przepisy prawne. Jeśli tak, to po drugie, w jaki sposób należy to robić. Odpowiedź na pierwsze pytanie jest związana ze znanym sporem - czy źródłem prawa jest samo prawo wydane przez władzę (prawo pozytywne), czy też źródłem prawa mogą być również normy pozaprawne (prawo naturalne). Spór nie został rozstrzygnięty, a w literaturze już pojawiają się nowe punkty widzenia (L. Morawski, Główne problemy wspótczesnej filozofii prawa: prawo $w$ toku przemian, Warszawa 2006). Celem tego artykułu nie jest rozwiązanie tego sporu, dlatego ta kwestia zostanie rozwiązana w sposób zwyczajowo przyjęty. Jak przypomina J. Oniszczuk: „Najczęściej uważa się, że nauka - teoria prawa - głównie zorientowana jest na konstruowanie twierdzeń o prawie badanym z punktu widzenia formalnego i realnego. Z kolei filozofia prawa zajmuje się zwłaszcza rozważaniami skierowanymi na istotę prawa, na to, czym ono jest, stawia też kwestie, jakie prawo być powinno, jaką stanowi wartość, jakim wartościom ma służyć, czy też jaką uzyskuje legitymację ideologiczną. Wreszcie jurysprudencja ogólna (generalna) zajmuje się przede wszystkim porządkowaniem aparatury pojęciowej, a także rozwiązuje ogólne problemy dogmatyczne" (J. Oniszczuk, Filozofia i teoria prawa, Warszawa 2008, s. 3). Ze względu na specyfikę zagadnienia, przedmiotowe badania można zakwalifikować do filozofii prawa. 
jednego z najbardziej znanych jej propagatorów, australijskiego filozofa i etyka P. Singera.

Bardzo istotny jest punkt wyjścia etyki utylitarystycznej, zgodnie z którym „winniśmy brać pod uwagę interesy każdej istoty odczuwającej skutki danego czynu i winniśmy traktować je tak samo jak podobne interesy wszelkich innych istot"39. Posiadanie interesów nie jest rozumiane dowolnie. P. Singer odwołuje się do angielskiego prawnika i filozofa J. Benthama, który stwierdził: „Należy pytać nie o to, czy zwierzęta mogą rozumować ani czy mogą mówić, lecz czy mogą cierpieć"40. Powołując się na Benthama, Z. Piątek konstatuje: „Liczą się jedynie interesy, zaś minimalnym warunkiem (warunkiem wstępnym) ich posiadania jest zdolność do odczuwania bólu i/lub przyjemności"41. Zdolność odczuwania bólu i przyjemności jest warunkiem koniecznym posiadania interesów, które z kolei są warunkiem włączenia danej istoty żywej do „uniwersum moralnego człowieka"42. Unikanie cierpienia jest oczywistym faktem biologicznym, który dotyczy wszystkich istot posiadających system nerwowy. Zwolennicy upodmiotowienia zwierząt, którzy powołują się na etykę utylitarystyczną, przyjmują kryterium fizjologiczne, aby wykazać, że w zakresie moralności tym, co naprawdę istotne dla wszystkich istot, jest unikanie cierpienia. J. Białocerkiewicz pyta wyraźnie: „Czym bowiem w sensie fizjologicznym człowiek różni się od zwierząt naczelnych? W zasadzie niczym, a jeżeli już to te różnice są niewielkie"43. Jeżeli między człowiekiem a zwierzętami nie ma różnicy, to jak ocenić wiodącą rolę człowieka? Peter Singer porównuje traktowanie zwierząt przez

39 P. Singer, Zwierzęta i ludzie jako istoty sobie równe, „Etyka” 1980, nr 18, s. 50 .

40 J. Bentham, Wprowadzenie do zasad moralności i prawodawstwa, Kraków 1958, rozdział 17.

41 U. Zarosa, Status moralny zwierząt a dwa rodzaje potencjalności, „Etyka praktyczna" 2012, nr 3, s. 66.

42 Z. Piątek, Etyka środowiskowa. Nowe spojrzenie na miejsca człowieka w świeci, Kraków 1998, s. 119.

43 J. Białocerkiewicz, Status prawny zwierząt, s. 203. Na s. 104 Białocerkiewicz przywołuje wypowiedź znanego brytyjskiego etologa, zoologa i ewolucjonistę R. Dawkinsa - ,istoty z teleologicznego punktu widzenia mają identyczne znaczenia, gdyż ich życie służy wyłącznie przetrwaniu gatunku”. 
ludzi do rasizmu i seksizmu: „I właśnie na tej podstawie należy oprzeć wszelkie argumenty przeciwko rasizmowi i seksizmowi; zasada ta nakazuje nam również potępić postawę, którą przez analogię do rasizmu możemy nazwać gatunkowizmem (szowinizmem gatunkowym). Gatunkowizm (nie jest to zbyt ładne słowo, ale lepsze nie przychodzi mi do głowy) - to uprzedzenie lub stronnicza postawa faworyzowania członków własnego gatunku kosztem innych"44. Postawa szowinizmu nie jest moralnie relewantna i musi znaleźć odpowiednią ocenę. W ocenie J. Białocerkiewicza „w literaturze popularno-naukowej i naukowej pojawiają się radykalne tezy, według których człowiek dopuszcza się nieusprawiedliwionego zwierzożerstwa, polegającego na masowym zabijaniu i zjadaniu zwierząt pomimo tego, że nie jest to konieczne do jego przetrwania"45. Należy dodać, że zakaz „zwierzożerstwa” dotyczy tylko ludzi. Jak podkreśla Z. Piątek: „zdaniem Singera fakt, że zwierzęta drapieżne zjadają inne zwierzęta nie może stanowić racji dla ludzkich upodobań do zjadania mięsa, gdyż nie ma tu żadnej analogii" ${ }^{46}$.

Mogłoby się zatem wydawać, że P. Singer proponuje po prostu przyznanie zwierzętom takich samych praw podstawowych, przede wszystkim ochrona życia i wolność od cierpień. Okazuje się jednak, że zrównanie ludzi i zwierząt ma swoją specyfikę. Jak stwierdza U. Zarosa: „Singer uznaje utylitarystyczne argumenty dopuszczające zabijanie niektórych zwierząt, o ile będzie ono bezbolesne" 47 . Tę specyfikę w kwestii ochrony życia P. Singer wyjaśnia poprzez odwołanie się do pojęcia osoby. Zdaniem P. Singera, aby być „osobą”, trzeba spełniać określony zestaw kryteriów, a ich spełnienie nie musi ograniczać się tylko do ludzi. Według niego osoba jest ,istotą myślącą i inteligentną, obdarzoną rozumem i zdolnością refleksji, istotą, która może

44 P. Singer, Wyzwolenie zwierzat, Warszawa 2004, s. 18.

45 J. Białocerkiewicz, Status prawny zwierzq̨t, s. 19. Nazwanie tych, którzy żyją dzięki pokarmom mięsnym szowinistami i zwierzożercami ma już jednoznaczną wymowę - nie jest to tylko stwierdzenie faktu, co jest oczywiste przy prowadzeniu badań, ale jednocześnie dokonuje się jednoznacznych ocen i sądów w stosunku do tych, którzy inaczej postrzegają problem.

46 Z. Piątek, Etyka środowiskowa, s. 121.

47 U. Zarosa, Status moralny zwierząt, s. 66. 
ujmować siebie myślą jako samą siebie, to znaczy: jako tę samą w różnych czasach i miejscach myślącą rzecz" ${ }^{3}$. Przedstawiony opis odnosi się do gorylicy Koko, choć przywołując te kryteria, Singer odwołuje się do Boecjusza, św. Tomasza z Akwinu i J. Locka. P. Singer przypomina słynną definicję osoby według Boecjusza: naturae rationalis individua substantia, co na podstawie swoich poszukiwań tłumaczy: „jednostkowa substancja o naturze racjonalnej”49. Zaznacza, że: „definicję tę przejął potem Tomasz z Akwinu i inni myśliciele, a Locke uzupełnił ją o aspekt świadomości własnego istnienia w różnych miejscach i czasie" $"$.

W swoim fundamentalnym dziele „Etyka praktyczna” analiza pojęcia osoby zajmuje Singerowi zaledwie dwa akapity. Co istotne, analiza tego pojęcia prowadzi P. Singera do przekonania, że nie każda istota ludzka jest osobą: „Użycie »osoby« samo w sobie, niestety, może wprowadzać w błąd, jako że »osoba « jest często używana w tym samym znaczeniu co »istota ludzka«. Ale terminy te nie są ekwiwalentne; może być osoba, która nie jest przedstawicielem naszego gatunku. Mogą być także przedstawiciele naszego gatunku, którzy nie są osobami. Słowo »osoba« ma swoje źródło w łacińskim terminie oznaczającym maskę zakładaną przez aktora w klasycznym dramacie. Przez założenie maski aktorzy zaznaczali, że odgrywają rolę. Później »osoba« zaczęła znaczyć kogoś, kto odgrywa rolę w życiu, kto jest wykonawca czynności. Według Oxford Dictionary jednym z aktualnych znaczeń terminu jest »samoświadoma czy racjonalna istota«. To znaczenie ma niezaprzeczalnych filozoficznych poprzedników. John Locke zdefiniował osobę jako »istotę myślącą i inteligentną, obdarzoną rozumem i zdolnością do refleksji, istotę, która może ujmować siebie myślą jako samą siebie, to znaczy: jako tę samą w różnych okresach i miejscach

48 P. Singer, O życiu i śmierci, s. 199.

49 W przypisie do tego tłumaczenia składa podziękowanie Paoli Cavalieri, która znalazła dla niego ten cytat w książce XIX-wiecznego filozofa niemieckiego Fridricha Adolfa Trendelenburga, A Contribution to the History of the Word Person, „Monist”, t.20, 1910, s. 336-363.

50 P. Singer, O życiu i śmierci, s. 198. 
myślącą rzecz « (...), proponuję używać »osoby « w znaczeniu racjonalnej i samoświadomej istoty, by uchwycić te elementy popularnego znaczenia »istoty ludzkiej«, których nie obejmuje termin »przedstawiciel gatunku Homo sapiens «"51. Gatunek Homo sapiens rozumiany jest biologicznie, czyli człowiek jako gatunek od chwili poczęcia do śmierci. Traktowanie ludzi przede wszystkim jako członków gatunku jest szczególnie istotne. Podstawowym przekonaniem utylitaryzmu jest założenie, że człowiek jest tylko ewolucyjnym przedłużeniem takich czy innych zwierząt, że ,jesteśmy jedną z odrośli gatunku zwierzęcego"52. Jak podkreśla Singer: „Darwin nauczył nas, że także my jesteśmy zwierzętami, a nasze pochodzenie jest równie naturalne jak innych zwierząt. W pracy $O$ pochodzeniu człowieka z naciskiem podkreśla fakt, że dzielą nas od nich jedynie różnice stopnia, a nie rodzaju" ${ }^{53}$. Analizując pojęcie osoby P. Singer, który jest filozofem, odwołuje się przede wszystkim do nauk przyrodniczych, a dorobek filozofii w zasadzie jest przez niego ignorowany.

W ślad za nim idą również zwolennicy upodmiotowienia zwierząt. J. Białocerkiewicz zastrzega, że oczywiście między ludźmi i zwierzętami są różnice, ale z jego punktu widzenia są to różnice nieistotne: „Niezależnie od takiego lub innego stanowiska z całą pewnością możemy przyjąć, że wszystkie formy życia posiadają wspólne cechy, które można uznać za wiodące, a mianowicie: narodziny; śmierć; reprodukcja; przekazywanie cech genetycznych; dobór naturalny"54.

Utylitarystyczny podział wszystkich żywych stworzeń ma swoją specyfikę. W toku swoich analiz P. Singer podzielił ludzi i zwierzęta na osoby, istoty świadomie odczuwające oraz istoty nieświadome. Fundamentem rozważań, czy to osób czy nie-osób jest utylitarystyczna korzyść. Według tych kryteriów P. Singer określa, komu żyć warto a komu nie warto, wobec kogo mamy moralne obowiązki, które rozumiane są utylitarystycznie. Z tych rozważań wynika, że pełne prawa ochrony życia przy-

51 P. Singer, Etyka praktyczna, Warszawa 2003, s. 92-93.

52 J. Białocerkiewicz, Status prawny zwierzat, s. 95.

53 P. Singer, O życiu i śmierci, s. 188.

54 J. Białocerkiewicz, Status prawny zwierzat, s. 104. 
sługują osobom, które spełniają kryteria definicyjne. Na podstawie tych kryteriów P. Singer wnosi, że osobą jest nie tylko gorylica Koko, ale dotyczy to zapewne także innych wielkich małp człekokształtnych, i to nie tylko tych, które uczą się ludzkiego języka ${ }^{55}$. Zatem do osób zostają zaliczeni ludzie (z pewnymi ograniczeniami, o których poniżej), a także szympanse, goryle, orangutany, wieloryby, delfiny, małpy, psy, koty, a być może, zastawia się Singer, również wszystkie ssaki ${ }^{56}$. W związku z tym, że prawo do życia nie przysługuje w sposób bezwzględny, ale podlega ocenie korzyści, nie przysługuje więc tym istotom, które nie spełniają właściwych kryteriów. Zalicza do nich istoty świadomie odczuwające, a więc np. dzieci nienarodzone, dzieci krótko po urodzeniu (Singer nie wie, jak krótko, z jego rozmów z 2,3-latkami wynika, że takie dzieci nie wiedzą, czym jest śmierć ${ }^{57}$ ), a także innym, którzy są chorzy, a ich rokowania nie są pomyślne ${ }^{58}$. Taka analiza, polegająca na wyliczeniu cech, które omawia się z punktu widzenia utylitaryzmu klasycznego i utylitaryzmu preferencji, oznacza w praktyce, że przyznanie statusu osoby dokonuje się w sposób zasadniczo uznaniowy, ponieważ wymagane jest posiadanie zestawu kilku cech, którymi muszą charakteryzować się istoty żywe, aby zaliczyć je do grona osób. Czy swoje badania dotyczące zwierząt P. Singer przeprowadził podobnie jak badania dotyczące osoby? Nie wiadomo, ponieważ w tym zakresie powołuje się on na badania przedstawicieli nauk przyrodniczych ${ }^{59}$.

55 P. Singer, O życiu i śmierci, s. 199.

56 P. Singer, Etyka praktyczna, s. 132.

57 Ibidem - rozdział 6.

58 Ibidem - rozdział 7.

59 Nie podważając wszystkich badań, trzeba zaznaczyć, że czasami pojawiają się w tym zakresie pewne wątpliwości dotyczące wiarygodności badań. Przywołam tu tylko dwa przykłady: 1. Jane Goodall, słynna badaczka szympansów, wykorzystała w swojej książce treści z Wikipedii, bez podania źródła - http://fakty.interia.pl/nauka/news-slynna-badaczka-szympansowoskarzana-o-plagiat,nId,945614. 2. Biolog Justin Gregg dowodzi, że delfiny, które uważano dotychczas za wyjątkowo inteligentne ssaki, jednak nie są tak inteligentne - http://tvnmeteo.tvn24.pl/informacje-pogoda/ciekawostki, 49/delfiny-nie-takie-madre-jak-myslelismy-sa-tak-samo-bystre-jakkurczaki,100516,1,0.html. 
Podsumowując, należy przypomnieć, że fundamentem etyki utylitarystycznej jest unikanie cierpienia i dążenie do przyjemności. P. Singer i jego zwolennicy często przywołują powiedzenie J. Benthama: „»prawa naturalne« to »nonsens«, a »niezbywalne prawa naturalne tu «"60. W tym samym duchu wypowiada się P. Singer i zwolennicy upodmiotowienia zwierząt. Zatem, wyjątkowej ochronie zwierząt, towarzyszy uznaniowość w kwestii statusu osoby i wynikających z tego decyzji o tym, kto ma prawo do życia. W świetle etyki utylitarystycznej, wartość absolutna przyznana jest interesom, które rozumie się jako powiększanie przyjemności i unikanie cierpienia. Absolutna wartość interesów przewyższa nawet wartość życia. Przyjęte założenie ma swoje konsekwencje, a P. Singer wyprowadza z tych założeń logiczne konsekwencje.

\section{FILOZOFICZNA OCENA UTYLITARYZMU P. SINGERA}

Ocena utylitaryzmu P. Singera nie jest zadaniem łatwym. Po pierwsze, jak wspomniano w rozdziale 2, retoryka P. Singera przypomina raczej wojnę cywilizacyjną. Będąc naukowcem, w zasadzie nie omawia materiału historycznego prezentowanego tematu, ale już na samym początku dokonuje oceny całego dorobku kultury zachodniej. Jednocześnie wybiera sobie z tego dorobku takie cytaty, które odpowiadają prowadzonemu przez niego rozumowaniu. Co więcej, tok rozumowania prowadzony jest $\mathrm{w}$ taki sposób, że czytający albo zgodzi się z autorem, albo jest szowinistą. Długie passusy opisujące patologiczne traktowanie zwierząt, wykorzystane są do oceny tych, którzy mają zdanie inne niż prezentowane przez P. Singera (niestety, J. Białocerkiewicz, Ł. Smaga i T. Pietrzykowski ulegli tej retoryce i w swoich książkach prowadzą bardzo podobny tok rozumowania). Co wynika z tych dwóch uwag? Jak zauważa H. Ciach w swojej

60 P. Singer, Wyzwolenie zwierząt, s. 19. 
książce na temat bioetyki P. Singera: „Tak styl pisania jest charakterystyczny bardziej dla publicystów niż dla naukowców"61. Czy w tej sytuacji możliwy jest spokojny i rzetelny dyskurs?

Druga trudność jest jednym z problemów tej pracy, a mianowicie próba zbadania prawnego problemu upodmiotowienia zwierząt, prowadzi w inne wyspecjalizowane dziedziny nauki. Poza teorią i filozofią prawa, wyżej wymienieni autorzy prezentują w swoich pracach dorobek etyczny, filozoficzny, teologiczny, światopoglądowy i dotyczy to nie tylko kręgu kultury europejskiej czy szerzej zachodniej, ale także kultur Dalekiego Wschodu. Takie odwołania mogą okazać się cenne, ale przywoływanie wyrwanych z kontekstu zachowań buddyjskich mnichów jest raczej mało przekonujące. Autorzy nie prowadzą przecież badań z zakresu antropologii kulturowej czy teologii, ale wybierają sobie takie przykłady, które akurat pasują do ich przekonań, nie tylko naukowych, ale także światopoglądowych.

W związku z powyższym, ocena propozycji P. Singera i jego propagatorów, zostanie dokonana w następujący sposób. Najpierw zostanie przedstawiona ocena źródeł utylitaryzmu. Następnie, w niezbędnym zakresie, utylitarystyczna koncepcja osoby zarysowana przez P. Singera, zostanie zaprezentowana w świetle współczesnych dokonań filozofii człowieka. Wnioski wynikające z tych rozważań, zostaną poddane ocenie z perspektywy prawnej w podsumowaniu artykułu.

Fundamentem etyki utylitarystycznej jest przede wszystkim korzyść. Czy będzie to utylitaryzm klasyczny i korzyść rozumiana jako przyjemność, czy będzie to utylitaryzm preferencji i prowadzenie quasi-matematycznych analiz sumy szczęścia i opłacalności, to cały czas pozostajemy w zakresie korzyści. Jako filozof i etyk P. Singer ma świadomość, że etyka utylitaryzmu klasycznego obarczona jest błędem naturalistycznym, przed którym przestrzegał D. Hume, a mianowicie, że ze zdań opisowo-teoretycznych nie powinno się wyprowadzać powinno-

61 H. Ciach Istota ludzka czy osoba ludzka? Krytyka bioetyki początków życia Petera Singera, Kraków 2013, s. 17. 
ści i oceny zachowań ${ }^{62}$. Peter Singer deklaruje się zatem jako utylitarysta preferencji, gdzie korzyści zostają uogólnione i są analizowane w sposób naukowy, czy wręcz ekonomiczny. Taki utylitaryzm prowadzi do buchalterii wyborów moralnych i jest niewykonalny dla przeciętnego człowieka ${ }^{63}$. Jak przestrzega R. Spaemann, „utylitaryzm sprawia, że zwykli ludzie w swym osądzie moralnym byliby całkowicie zdani na techniczną inteligencję ekspertów; zamienia się normy moralne na techniczne"64. Taka moralność przestaje być moralnością, a zaczyna być sztuką ${ }^{65}$. Jak stwierdza R. Spaemann „w utylitaryzmie bowiem nie można odczytać moralnej wartości czynów z nich samych, lecz trzeba ją obliczyć według uniwersalnego wzoru na powiększanie korzyści. Jego stworzenie jest rzeczą ekspertów, choćby samozwańczych"66.

Mówienie o korzyściach w ramach etyki musi w końcu doprowadzić do ekonomicznego aspektu tych korzyści. Oznacza to, że życie ludzkie nie ma wartości samej w sobie, a Singer zaczyna się zastanawiać, czy utrzymywanie człowieka przy ży-

62 D. Hume Traktat o naturze ludzkiej, Warszawa 1963, t. 2, s. 259-260 .

63 Etyka utylitaryzmu jest dla superinteligentów, [w:] portal etyki akademickiej „Etyka praktyczna”. http://etykapraktyczna.pl/wpis/2010/06/24/ etyka-utylitaryzmu-jest-dla-superinteligentow Zaprezentowana dyskusja prowadzi to konkluzji, że aby dokonać właściwego wyboru moralnego na podstawie etyki preferencji, należałoby wykorzystać system komputerowy do wyboru właściwego rozwiązania.

64 R. Spaemann, Podstawowe pojęcia moralne, Lublin 2000, s. 58.

65 P. Jaroszyński przypomina, że „Kryterium podziału nauk jest cel. Wyróżnia się te, których celem jest wytwór - i to są nauki poetyczne (ఐoínбıs [póiesis] - wyrób, wytwór); celem innych jest działanie ( $\rho \tilde{\alpha} \xi_{1} \varsigma$ [praksis] działanie, czynność) - to są nauki praktyczne,; a wreszcie są nauki, których celem jest samo poznawanie ( $\theta \varepsilon \omega$ pí $\alpha$ [theoría])", [w:] P. Jaroszyński, Człowiek i nauka. Studium z filozofii kultury, Lublin 2008, s. 63. Autor scala w jednym miejscu teksty Arystotelesa i w przypisie wskazuje na ich źródła - Metafizyka, Topiki i Etyka nikomachejska.

66 R. Spaemann, Podstawowe pojęcia moralne, s. 58. Dodać należy, że w ostatnich latach mnożą się tzw. etyki zawodowe, specjalistyczne itp. „Specjaliści-etycy" tworzą etyki zawodowe, firmowe, korporacje, w których ustalono jakie zachowania są dobre a jakie złe. 
ciu po prostu się opłaca ${ }^{67}$. Tak rozumiana etyka, uderza przede wszystkim w najsłabszych. E. Picker przestrzega przed tym niebezpieczeństwem: „Brak prawa do życia i płynącego z niego interesu w jego ochronie z góry każą wykluczyć jakiekolwiek godne uwagi interesy przeciwne po stronie dziecka. Przy takim założeniu interesy »uprawnionych do życia « osób trzecich mają per se pierwszeństwo, a nawet są jedynymi interesami, które wchodzą w grę" 68 . Trzeba wyraźnie zaznaczyć, że relatywizacja życia osób najsłabszych, doprowadza do naruszenia fundamentów życia społecznego: „Wobec nieuniknionych konsekwencji, jakimi są w społeczeństwie głęboki niepokój i egzystencjalne obawy, taka koncepcja utylitaryzmu [Singera - przyp. D.M.] zawodzi już u swoich podstaw, gdyż z powodu filozoficznie uzasadnionej relatywizacji życia jednostka nie może być już pewna nawet własnego życia"69. Relatywizacja prawa do życia nie jest tylko wyrazem indywidualnych poglądów, ale jest nierozerwalnie związana z istotą utylitaryzmu. Zgodnie z tezą T. Pietrzykowskiego: „Dopuszczalność pozbawienia życia człowieka ze względu na rozmaite szczególne względy i okoliczności zawsze obecna była w dyskursie moralnym i prawnym. Od obrony koniecznej, przez karę śmierci, prowadzenie wojny (przynajmniej »sprawiedliwej«) po rozmaite »licencje« na zabijanie - wszystko to stanowi nieodłączny element tradycyjnych doktryn moralnych i regulacji prawnych"70. Pietrzykowski zestawia obok siebie obronę konieczną i karę śmierci, która w cywilizowanych krajach nie jest już wykonywana albo odchodzi się od niej. Obrony koniecznej można w jego przekonaniu użyć jako argumentu za relatywizacją życia i zezwoleniem na eutanazję. E. Picker wyraźnie przed tym przestrzega: „Fundamentalnego rozróżnienia, które ma rozstrzygać o życiu i śmierci, dokonuje się tu zatem na podstawie dowolnej, subiektywistycznie i woluntarystycznej

67 P. Singer, Etyka praktyczna, s. 90.

68 E. Picker, Godność człowieka a życie ludzkie. Rozbrat dwóch fundamentalnych wartości jako wyraz narastającej relatywizacji człowieka, Warszawa 2007, s. 26.

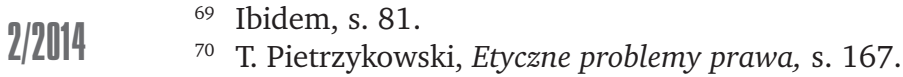


oceny"71. Niniejszy artykuł nie stawia sobie za cel wyjaśnienia, jakie powinny być źródła moralności, jednak historia ludzkości pokazuje nad wyraz dobitnie, że korzyść nie może być punktem wyjścia moralności. Można mieć także poważne wątpliwości, czy oparcie ludzkich wyborów moralnych na korzyściach jest w stanie uwzględnić dobro zwierząt.

Kolejnym doniosłym zagadnieniem jest utylitarystyczna koncepcja osoby. Ma ona szczególne znaczenie w zakresie upodmiotowienia zwierząt, dlatego należy poświęcić jej nieco więcej miejsca. Badając jej podstawowe założenia, można zauważyć, że charakterystyczne jest odwołanie do biologicznych aspektów natury ludzkiej. Człowiek jest oczywiście częścią świata przyrody, ale natura ludzka nie sprowadza się tylko do tych aspektów. Pytanie o człowieka pojawiało się najczęściej w sytuacji bolesnych doświadczeń wojen i totalitaryzmów. Odwołując się do tej sytuacji, G. Haeffner przypomina: „Odkąd człowiek ją sobie uświadomił, pytanie o własną istotę coraz częściej zaczęło wchodzić w krąg zainteresowań filozofii - zresztą było ono w niej obecne od początku, chociaż bez osobnego działu, opatrzonego tytułem »antropologia filozoficzna «"72. Ta dziedzina nauki nie odrzuca ani faktów biologicznych, ani faktów społecznych, „nie może jednak opierać się na samych badaniach empirycznych; zależy ona także od innych dyscyplin filozoficznych, na przykład od ontologii, etyki, filozofii przyrody, teorii poznania i estetyki"73. G. Haeffner wyraźnie zaznacza, że „antropologii filozoficznej nie konstruuje się »W nawiązaniu“ do teorii ewolucji, gdyż wtedy nie wyszłaby poza ramy biologii; przysługuje jej autonomia stawiania problematyki filozoficznej" ${ }^{\prime 4}$. Z tych podstawowych ustaleń wynika, że prowadząc badania dotyczące istoty zwierząt i ludzi, a zwłaszcza kwestii życia i śmierci, nie można poprzestać na biologii. Jest to podejście redukcjonistyczne.

71 E. Picker, Godność człowieka a życie ludzkie, s. 83.

72 G. Haeffner Wprowadzenie do antropologii filozoficznej, Kraków 2006, s. 11 .

73 Ibidem, s. 11.

74 Ibidem, s. 12. 
Uwzględniając dorobek antropologii filozoficznej, należy stwierdzić, że utylitaryzm należy do jednego z nurtów antropologii przyrodniczej. I. Bittner przypomina w swojej klasyfikacji: „Rzecznicy antropologii zorientowanej przyrodniczo, czy też raczej: naturalistycznie dopatrują się w naturze człowieka animalności. Operując dość bogatym materiałem, gromadząc go i uogólniając dane, oparte na badaniach empirycznych, chętnie posługują się analogiami organicystycznymi, stanowiącymi rodzaj analogii antropomorficznych. Posługując się często nośnymi filozoficznie i literacko formułami człowieka, prawie równie często dokonują nieuprawnionych ekstrapolacji, zwłaszcza metod nauk przyrodniczych na obszar nauk społecznych i humanistycznych"75. Właśnie takiej ekstrapolacji dokonał T. Pietrzykowski w swojej książce „Etyczne problemy prawa”. Przywołując koncepcję emotywizmu, który „uznaje, że istota wypowiedzi oceniającej stanowi wyraz reakcji emocjonalnej oceniającego zbliżonej do okrzyków »aua!«, »hurra!« czy »bu!«"76, sprowadza ludzki sposób wyrażania emocji do kilku zwierzęcych okrzyków. Takie zrównanie człowieka i zwierzęcia ma nie tylko charakter dyskusji akademickiej, ale prowadzić może do nieoczekiwanych konsekwencji. Swoistą kwintesencją naturalistycznego pojmowania człowieka, jest wypowiedź członka Rady Kornwalii Colina Brewera, który stwierdził: „Jesteśmy tylko zwierzętami. Nie możemy sobie pozwolić na baranki biegające $\mathrm{z}$ pięcioma nogami i dwiema głowami. Takie po prostu usuwa się ze stada"77.

Mimo że koncepcja osoby nie należy do nauk przyrodniczych, P. Singer dokonał właściwie jej całkowitej naturalizacji. Prezentując koncepcję osoby na podstawie Boecjusza, św. Tomasza z Akwinu i J. Locka, Singer nie przeprowadza filozoficznej analizy tej koncepcji. Standardem w filozofii jest analiza historyczna, natomiast Singer zatrzymuje się na postaci J. Locke'a,

75 I. Bittner, Filozofia człowieka. Zarys dziejów i przegląd stanowisk, Łódź 2000, s. 165-166.

76 T. Pietrzykowski, Etyczne problemy prawa, Warszawa 2011, s. 37.

77 Ta wypowiedź nie wymaga komentarza. Źródło: http://www.pch24.pl/ brytyjski-polityk--czlowiek-to-zwierze---niepelnosprawnych-mozna-zarznac,14913,i.html. 
który żył w wieku XVII i prezentuje tę koncepcję tak jakby definiował jakichś przedmiot. Daje do zrozumienia, że od Locke'a nie powiedziano już niczego istotnego w zakresie filozofii człowieka. Wobec powyższego, konieczne jest krótkie przypomnienie kilku najważniejszych elementów tej koncepcji.

Jakkolwiek, perspektywa św. Tomasza z Akwinu ani nie jest pierwszą filozoficzną refleksją nad człowiekiem, ani też ostatnią, to jednak uwzględnia ona dorobek antyczny (Arystoteles, Boecjusz, Awerroes), ale również, może stanowić punkt wyjścia dla dalszych poszukiwań. Podsumowanie koncepcji osoby św. Tomasza z Akwinu, przedstawił w zwięzłej formie W. Cichosz: „W kontekście powyższego dyskursu filozoficznego można postawić kilka zasadniczych tez uogólniających, porządkujących i charakteryzujących koncepcję osoby ludzkiej zaproponowaną przez św. Tomasza z Akwinu:

- na pojęcie osoby składa się samoistność, rozumność $\mathrm{i}$ istnienie jednostkowe;

- w skład Tomaszowej »osoby« wchodzi także całkowitość, a zatem odrębnie istniejąca dusza ludzka nie jest osobą;

- nazwa osoby wskazuje na nierozłączność albo na indywidualność bytu istniejącego w jakiejkolwiek naturze;

- osobą jest konkretny człowiek, co oznacza jedyność i niepowtarzalność;

- osoba jest czymś daleko więcej niż jedynie zindywidualizowaną naturą;

- w ujęciu św. Tomasza nie każdy byt indywidualny jest osobą, choć zawarty jest w rodzajowym pojęciu substancji, ale tylko taki byt, który istnieje sam przez siebie (per se);

- Akwinata pod pojęciem osoby rozumie niezależność od jakiejś całości. Osoby ludzkiej nie da się sprowadzić do jakiejkolwiek wartości ziemskiej, gdyż człowieka konstytuują i ciało, i dusza, która jest duchowa, niematerialna i ponadczasowa;

- jedynie człowiek może być nazywany osobą, gdyż jest jedynym bytem jednostkowym (singulare) o naturze rozumnej, istniejącym w świecie przyrodzonym. 
Święty Tomasz z Akwinu zachowuje zatem substancjalistyczną teorię osoby ludzkiej, czerpiąc zarówno z Arystotelesa, jak i z Boecjusza"78.

Dla niniejszych rozważań, które charakteryzuje perspektywa prawna, szczególnie istotne są dwie kwestie. Po pierwsze, uznanie, że człowiek to nie tylko ciało, ale połączenie ciała i duszy $^{79}$. „Połączenie ciała i duszy jest więc (...) zasadą ujednostkowienia człowieka, stanowi ontologiczną podstawę czyniącą każdego człowieka indywidualną niepowtarzalną osobą - osobą ludzką (persona humana)" 80 . Oznacza to, że w sensie bytowym, człowiek różni się od roślin i zwierząt. Jest to różnica istotowa, a nie tylko przypadłościowa. Po drugie, człowiek funkcjonuje jako istota rozumna (intelectus agens) i wolna, czyli zdolna do „samorzutnych czynów"81. Oznacza to, że człowiek, w odróżnieniu od zwierząt, może podejmować odpowiedzialność. Jest tak dlatego, że człowiek jest istotą rozumną, czyli zdolną do poznania, ale jest także istotą wolną, a więc może nakładać na siebie obowiązki, przede wszystkim w stosunku do innych ludzi.

Szczególny rozwój koncepcji osoby następuje w XIX w., w ramach nowego kierunku filozoficznego, który nazwano później personalizmem. Jednym z czołowych przedstawicieli tego kierunku był J. Maritain. W swoich badaniach przede wszystkim odwołuje się do tradycji a jednocześnie doprecyzowuje niektóre elementy koncepcji osoby: „Jedynie osoba jest wolna, jedynie osoba posiada $\mathrm{w}$ pełnym znaczeniu tego słowa wewnętrzność i podmiotowość, gdyż panuje nad sobą i bada samą siebie" Jednym z jego szczególnych osiągnięć jest wskazanie na różnicę między osobą a jednostką: „W świecie ducha człowiek uczestniczy jako osoba, zaś jako jednostka pojawia się w świecie materii. Zatem osoba jako byt uczestniczący w duchowym sposobie istnienia posiada najwyższą godność. Uznanie dla osoby czło-

78 W. Cichosz, Koncepcja osoby ludzkiej w filozofii św. Tomasza z Akwinu, „Studia Gdańskie”, t. XIII, Gdańsk 2000, s. 184.

79 Należy pamiętać, że nie jest to dusza w sensie teologicznym.

80 I. Bittner, Filozofia człowieka, s. 43.

81 Ibidem, s. 45.

82 J. Maritain, Pisma filozoficzne, Kraków 1988, s. 85. 
wieka jest podstawowe dla znaczenia dobra wspólnego. Personalistyczne państwo ma chronić wolność osoby, rozwijać jej autonomię"83. J. Maritain w sposób szczególny podkreśla godność osoby ludzkiej. Fundamentem tej godności jest duchowy aspekt istnienia człowieka, który pozwala człowiekowi panować nad sobą. Tak rozumiany człowiek jest wyjątkowy sam w sobie. Każdy członek społeczeństwa jest dobrem, które państwo powinno chronić. Ma to oczywiście swoje konsekwencje w zakresie tworzenia i stosowania prawa - państwo jest dla człowieka, a nie odwrotnie. Państwo nie nadaje człowiekowi godności, ono ją chroni.

Filozofia osoby zostaje podjęta również w XX w. Szczególne zasługi w tym zakresie przypisuje się osobie M. Schelera, którego uważa się za ojca współczesnej antropologii filozoficznej. W ramach prowadzonych przez siebie badań, wyjaśnia on problem, który jest podnoszony przez współczesnych zwolenników upodmiotowienia zwierząt. Jak prezentowano w rozdziale 3 , uważają oni, że różnica między zwierzęciem a człowiekiem jest różnicą stopnia a nie różnicą rodzaju. M. Scheler przypomina, że „wszyscy ewolucjoniści szkoły Darwina i Lamarcka, odrzucają wraz z Darwinem, G. Schwalbem, a także W. Köhlerem jakąś ostateczną różnicę między człowiekiem a zwierzęciem, ponieważ właśnie zwierzę także posiada już inteligencję"84. Uwagi P. Singera dotyczące inteligencji zwierząt nie są zatem wielkim odkryciem, ponieważ kwestia ta była wyjaśniana już wcześniej. M. Scheler wyjaśnia dalej: „Byłoby jednak również chybione, gdyby to, co nowe, co czyni człowieka człowiekiem, pojęło się tylko jako pewien - dołączający się jeszcze do psychicznych stopni: pęd uczuciowy, instynkt, pamięć asocjacyjna, inteligencja i wybór - nowy istotnościowy stopień przynależnych do sfery witalnej funkcji i zdolności psychicznych, których poznanie leżałoby zatem w kompetencji psychologii i biologii" ${ }^{85}$. M. Scheler zwraca uwagę na fakt, który został szczególnie mocno wyar-

83 J. Oniszczuk, Filozofia i teoria prawa, Warszawa 2008, s. 213.

84 M. Scheler, Stanowisko człowieka $w$ kosmosie, [w:] Pisma z antropologii filozoficznej i teorii wiedzy, Warszawa 1987, s. 81.

85 Ibidem, s. 81. 
tykułowany przez hermeneutykę, że są takie aspekty życia człowieka, które wykraczają poza nauki przyrodnicze ${ }^{86}$. Oznacza to przede wszystkim inną metodologię badań.

Tym, co w człowieku inne w stosunku do otaczającej go rzeczywistości przyrodniczej, jest dla M. Schelera duch: „Jeśli w pojęciu ducha wysuniemy na czoło jego szczególną funkcję poznawczą (Wissensfunktion), ten rodzaj wiedzy, której jedynie on może dostarczyć, wówczas podstawowym określeniem duchowej istoty, jakąkolwiek by ona była pod względem psychofizycznym, jest jej »egzystencjalne uwolnienie (Entbundenheit) od tego, co organiczne«, jej wolność, możność oderwania się - czy też wolność i możność oderwania się jej centrum bytowego - od władzy (Bann), nacisku, zależności od »tego, co organiczne«, od »życia« i wszystkiego, co do niego należy, a więc również od swojej własnej popędowej »inteligencji «"87. Wskazuje to na możliwość dystansu do otaczającej rzeczywistości. ,»Duchowa« istota nie jest już zatem uwarunkowana przez popęd i otoczenie, lecz jest »wolna od otoczenia «"88. To niezwykle istotne spostrzeżenie potwierdza znaną skądinąd prawdę, że człowiek pragnie wolności, że chce kształtować swoje życie niezależnie od swojego statusu majątkowego, a nawet od różnych uwarunkowań społecznych ${ }^{89}$. Do takich aktów zdolna jest tylko istota, która potrafi uwolnić się od swojego otoczenia. Konsekwencje dystansu do otoczenia mają wielorakie znaczenie, ale mają szczególne znaczenie w zakresie ludzkiego poznania. M. Scheler wyjaśnia, że „istota taka może pierwotnie także i jej dane ośrodki »oporu« i reakcji swego otoczenia, które zwierzę

${ }^{86}$ W ramach hermeneutyki XX-wiecznej należy wspomnieć przede wszystkim M.Heideggera i H.G.Gadamera. Max Scheler był przedstawicielem fenomenologii.

${ }^{87}$ M. Scheler, Stanowisko człowieka $w$ kosmosie, s. 83. Opierając się na badaniach W. Köhlera, Scheler przypisuje zwierzętom najprostsze działania inteligentne (s. 76).

88 Ibidem, s. 83.

89 Dowody takiej potrzeby są różne. Jeden z największych polskich poetów Cyprian Kamil Norwid, który całą swoją twórczość poświęcił dla ojczyzny, umarł w biedzie. Maksymilian Maria Kolbe dał się zagłodzić na śmierć w obozie koncentracyjnym Auschwitz, w zamian za innego więźnia. 
jedynie posiada, ekstatycznie się w nich roztapiając, podnieść do [poziomu] »przedmiotów « oraz uchwycić zasadniczo »samo uposażenie jakościowe (Sosein) tych przedmiotów, bez ograniczenia, jakiemu podlega ich świat bądź ich prezentowanie się przez witalny system popędów oraz wyprzedzające go (vorgelagerten) zmysłowe funkcje i narządy" ${ }^{\prime 90}$. Zdolność uchwycenia istoty przedmiotu jest podstawą abstrakcji ${ }^{91}$. „Dla zwierzęcia nie ma żadnych »przedmiotów«, wżywa się ono ekstatycznie w swoje otoczenie i otoczenie to, jako strukturę, przenosi wszędzie, dokąd się udaje, poniekąd jak ślimak swój dom; otoczenia tego nie może uczynić przedmiotem"92. Te dwie cechy, wolność od otoczenia i zdolność do uprzedmiotowienia, mają fundamentalne znaczenie $\mathrm{w}$ zakresie ludzkiego poznania i postępowania. W zakresie poznania, człowiek jest zdolny do poznania prawdy o przedmiocie. Jeżeli człowiek może oderwać się od różnych biologicznych i społecznych uwarunkowań, może wówczas rozpocząć właściwy proces poznawania. Ten proces nie jest łatwy, a dowodem na to jest historia nauki. Jednak bez postawienia przedmiotu „przed sobą” nie można mówić o prawdziwym poznaniu, poznaniu istoty rzeczy. W zakresie ludzkiego postępowania, człowiek, który poznaje istotę rzeczy, może podjąć wolną decyzję o sposobie swojego działania. Decyzji, która może być wolna od własnej zmysłowości. Konsekwencje takiej natury człowieka pozwalają mówić o ludzkim postępowaniu i zwierzęcym reagowaniu. W zakresie postępowania zgodnego z prawem, to nie prawo samo $\mathrm{w}$ sobie kieruje ludzkim postępowaniem, ale człowiek-osoba, który czując nacisk swoich wielorakich potrzeb, zna również prawo i jest w stanie podjąć autonomiczną decyzję. Ta decyzja nie zawsze doprowadzi do osiągnięcia celu (co jest tak istotne dla utylitarystów), ale właśnie ona określa człowieka, ponieważ tylko człowiek może w pełnym tego słowa znaczeniu postępować a nie tylko reagować.

90 Ibidem, s. 83.

91 Zdolność abstrahowania, odróżniającą człowieka od zwierząt, dostrzegał już św. Tomasz z Akwinu.

92 M. Scheler, Stanowisko człowieka $w$ kosmosie, s. 85. 
Co więcej, ta odmienność funkcjonowania dotyczy nie tylko czynności uważanych za czysto intelektualne. M. Scheler nie miał wątpliwości, że ten szczególny wymiar ludzkiego funkcjonowania „przemienia” człowieka w całej swej pełni: „Odpowiednia warstwa mianowicie właśnie u człowieka wtapia się w szerszą strukturę i jest tak spleciona $\mathrm{z}$ wymiarem zdolności mowy i abstrahowania, ze już w normalnym ludzkim zachowaniu funkcje czysto życiowe: sen, jedzenie, trawienie, kopulowanie, orientacja, reakcje obronne, są ustylizowane zupełnie inaczej niż u najbliżej spokrewnionych z nimi zwierząt"93. Człowiek różni się od zwierząt nie tylko dlatego, że żyje w społeczeństwie, ale przede wszystkim dlatego, że jest innym bytem. P. Singer kładzie w swoich badaniach nacisk na to co w człowieku biologiczne. Odrzucając badania z zakresu antropologii filozoficznej, nie tylko popełnił błąd metodologiczny, ale odrzucił także istotne fakty dotyczące człowieka.

Ta krótka prezentacja zostanie zakończona uwagami R. Spaemanna, który jest jednym z najwybitniejszych współczesnych filozofów i odniósł się wprost do propozycji P. Singera wskazując m.in., że „do nazywania ludzi osobami skłaniają nas określone ludzkie cechy. Osobami nie nazywamy jednak tych cech, lecz ich nosicieli. Istnieją oczywiście osoby, które nie mają takich cech. Mogłoby się zatem wydawać, że ludzie ci nie są osobami i nie mogą wnosić roszczenia do uznania ich za osoby. Tak właśnie brzmi - odwołująca się Locke’a - teza Petera Singera i Norberta Hörstera"94. R. Spaemann podnosi problem, który był wyraźnie widoczny, kiedy P. Singer analizował definicję osoby. Traktował on człowieka i zwierzę jak poszczególne przypadki, które podpadają lub nie podpadają pod standard określony przez tę definicję. Jakie są ostateczne konsekwencje takiego podejścia? Zabicie szympansa jest gorsze niż zabicie ludzkiej istoty, która, według Singera, z powodu wrodzonego umysłowego upośledzenia nie jest i nie może być osobą. Jak pisał: „Rodzice mogą, mając ku temu słuszny

93 H. Plessner, Pytanie i conditio humana, Warszawa 1988, s. 74.

2/2014 s. 291

94 R. Spaemann, Osoby. O różnicy miedzy czymś a kimś, Warszawa 2001, 
powód, żałować, że niepełnosprawne dziecko w ogóle się urodziło. W takim wypadku wpływ, jaki śmierć dziecka będzie mieć na rodziców, może przemawiać raczej za niż przeciw zabiciu"95. R. Spaemann wyraźnie wskazuje, że osoba jest nosicielem cech i nie musi dysponować każdą z tych cech. Między osobami a „zestawem” ich cech jest dystans, „osoby są »poza byciem«. Nie są one, jak wszelkie życie pozaosobowe, »byciem-ku-byciu«. Ich bycie-ku-byciu jest czymś, co mają i do czego mogą się odnosić. Nie sq̨ one swym przeżywaniem, są podmiotami przeżywania"96. Zdolność zdystansowania się do swojego otoczenia i siebie samego określa nie tylko ludzki sposób poznania i postępowania, o czym wspomniano przy analizie tekstów M. Schelera. Według R. Spaemanna, bycie podmiotem przeżywania wyróżnia człowieka spośród innych bytów i dotyczy wszystkich ludzi. Nie oznacza to dowolnego traktowania zwierząt, ale wskazuje na wyjątkowy status człowieka-osoby.

Analiza filozoficznej koncepcji osoby prowadzi do wniosku, że koncepcja osoby zaprezentowana przez P. Singera ma nie tylko swoje przerażające konsekwencje praktyczne, ale przede wszystkim jest nieprawdziwa. Co więcej, nie są to tylko dyskusje akademickie, ale Singer domaga się także ich zastosowana. Tak ludzie jak i zwierzęta, którzy pod jego definicję nie podpadają, mogą być „wyeliminowani”. Taka uprawianie filozofii przestaje być nauką i zaczyna być ideologią. Historia potwierdza, że tworzenie człowieka doskonałego według umownego schematu, prowadzić może do tragicznych konsekwencji.

95 P. Singer, Etyka praktyczna, s. 177.

96 R. Spaemann, Osoby, s. 194. Ta specyfika ludzkiej natury ma również swoje konsekwencje praktyczne. Jak pisał polski psychiatra A. Kępiński: „Lekarz nie leczy złamania nogi, choroby nerek, płuc, serca, lecz chorego ze złamaną nogą, chorego z uszkodzeniem nerek itp. Nie chodzi tu o odmianę słów, lecz o praktyczną i dość banalną uwagę, że leczymy chorego człowieka, a nie chory narząd" - A. Kępiński, Rytm życia, Kraków 2000, s. 276. 


\section{WNIOSKI}

Jak zatem ocenić propozycje P. Singera i jego zwolenników, $\mathrm{w}$ zakresie utylitarnych źródeł prawa, w tym przede wszystkim propozycję upodmiotowienia zwierząt?

Powyżej przypomniano, że godność człowieka jest źródłem praw człowieka. Peter Singer nie ukrywa, że podważa fundamenty praw człowieka i odrzuca aktualnie obowiązujące źródła praw. Godność człowieka, która jest źródłem tych praw jest dla niego pustosłowiem. Jednak godności ludzkiej nie można traktować w sposób utylitarny, a także sprowadzać do prostej definicji. „Posługując się pojęciem »godności człowieka«, ustawodawcy nie definiują jej, ale przyjmują ją jako pewną kategorię kulturową, wartość uniwersalną, wyrosłą na gruncie klasycznych nurtów filozofii europejskiej"' ${ }^{97}$. Nie jest to zatem trywialne przyznawanie człowiekowi jakiejś szczególnej godności, aby odróżnić człowieka od zwierząt. Uznanie godności człowieka jest efektem namysłu, który jest oparty na poznaniu człowieka w całej swej pełni, a nie tylko jego wybranych aspektów. Jak przypomina M. Sadowski: „Poza dyskusją jest teza głosząca, że idea godności człowieka jest nierozdzielnie związana z koncepcją osoby ludzkiej, jest ona bowiem jednym z fundamentalnych zagadnień współczesności, dotyczącym nie tylko kwestii teoretycznych, ale pociąga za sobą również ważkie konsekwencje praktyczne" 98 . P. Singer i jego zwolennicy nie ukrywają w swoich pracach redukcjonistycznej wizji człowieka. Jest to jednak wizja nieprawdziwa i może prowadzić do przerażających konsekwencji praktycznych. W związku z powyższym, koncepcja

97 J. Krukowski, Godność człowieka podstawa konstytucyjnego katalogu praw i wolności jednostki, [w:] Podstawowe prawa jednostki i ich ochrona, (red.) L. Wiśniewski, Warszawa 1997, s. 38.

98 M. Sadowski, Personalizm chrześcijański Jacques'a Maritain'a jako fundament koncepcji godności człowieka, [w:] Pozytywizm prawniczy i szkoła prawa natury: tradycje sporu i jego wspótczesne implikacje, (red.) P. Kaczmarek i Ł. Machaj, Wrocław 2010, s. 37, źródło: http://bibliotekacyfrowa.pl/publication/29514. 
upodmiotowienia zwierząt zaproponowana przez P. Singera musi być odrzucona.

Należy również zapytać, czy człowiek zredukowany do poziomu istoty socjobiologicznej jest w stanie traktować zwierzęta w sposób humanitarny? Nie ma wątpliwości, że bycie humanitarnym wymaga czasem rezygnacji z osobistych przyjemności lub korzyści. Tylko człowiek, który jest istotą nie tylko cielesną, ale także duchową, może podjąć proces kształtowania własnej osoby. Przypomniał o tym H.G. Gadamer: „Byt ducha jest bowiem z istoty związany z ideą kształcenia"99. Kształcenie jest procesem bardzo bogatym, który nie ogranicza się tylko do zdobywania teoretycznej wiedzy. Jego istotnym elementem jest kształcenie ludzkiej moralności, która nie musi być jedna dla wszystkich. Wymaga ono także, podejmowania wolnych i rozumnych wyborów. Wyborów, za które człowiek odpowiada, tak w aspekcie moralnym jaki i prawnym.

Sprowadzając człowieka do wymiaru socjobiologicznego, $\mathrm{w}$ istocie przekreśla się ten specyficznie ludzki aspekt. Mam wątpliwości, czy taki człowiek będzie w stanie traktować zwierzęta w sposób humanitarny.

\section{BIBLIOGRAFIA}

Banaszak B., Prawo konstytucyjne, Warszawa 2010.

Bentham J., Wprowadzenie do zasad moralności i prawodawstwa, Kraków 1958.

Białocerkiewicz J., Status prawny zwierząt. Prawa zwierząt czy prawna ochrona zwierzat, Toruń 2005.

Bittner I., Filozofia człowieka. Zarys dziejów i przegląd stanowisk, Łódź 2000.

Ciach H., Istota ludzka czy osoba ludzka? Krytyka bioetyki początków życia Petera Singera, Kraków 2013.

Cichosz W., Koncepcja osoby ludzkiej w filozofii św. Tomasza z Akwinu, „Studia Gdańskie”, t. XIII, Gdańsk 2000.

Dunaj B. (red.), Wielki stownik języka polskiego, Warszawa 2009.

Gadamer H.G., Prawda i metoda, Warszawa 2004.

99 H.G. Gadamer Prawda i metoda, Warszawa 2004, s. 38. 
Gardocka T., Gruszczyńska A. (red.), Status zwierzęcia. Zagadnienia filozoficzne i prawne., Toruń 2012.

Haeffner G., Wprowadzenie do antropologii filozoficznej, Kraków 2006. Hume D., Traktat o naturze ludzkiej, Warszawa 1963, t.2.

Jaroszyński P., Człowiek i nauka. Studium z filozofii kultury, Lublin 2008.

Jastrzębski L., Prawo ochrony środowiska w Polsce, Warszawa 1990.

Jasudowicz T., Konstrukcja normatywna międzynarodowo chronionych praw człowieka, [w:] Prawa człowieka i ich ochrona, praca zbiorowa, Toruń 2010.

Kępiński A., Rytm życia, Kraków 2000.

Krukowski J., Godność człowieka podstawa konstytucyjnego katalogu praw i wolności jednostki, [w:] Podstawowe prawa jednostki $i$ ich ochrona, (red.) L. Wiśniewski, Warszawa 1997.

Łapiński J., Etyczne podstawy ochrony zwierząt, [w:] Prawna ochrona zwierząt, (red.) M. Mozgawa, Lublin 2002.

Maritain J., Pisma filozoficzne, Kraków 1988.

Morawski L., Główne problemy wspótczesnej filozofii prawa: prawo $w$ toku przemian, Warszawa 2006.

Oniszczuk J., Filozofia i teoria prawa, Warszawa 2008.

Osiatyński W., Prawa człowieka i ich granice, Kraków 2011.

Pawłowski A., Odpowiedzialność człowieka za przyrodę. Humanizm ekologiczny, vol. 5, Lublin 1999.

Piątek Z., Etyka środowiskowa. Nowe spojrzenie na miejsca człowieka w świeci, Kraków 1998.

Picker E., Godność człowieka a życie ludzkie. Rozbrat dwóch fundamentalnych wartości jako wyraz narastającej relatywizacji człowieka, Warszawa 2007.

Piechowiak M., Pojęcie praw człowieka, [w:] Podstawowe prawa jednostki i ich ochrona. (red.) L. Wiśniewski, Warszawa 1997.

Pietrzykowski T., Etyczne problemy prawa, Warszawa 2011.

Pietrzykowski T., Spór o prawa zwierząt, Katowice 2007.

Plessner H., Pytanie i conditio humana, Warszawa 1988.

Radecki W., Ochrona walorów turystycznych $w$ prawie polskim, Warszawa 2011.

Radecki W., Ustawa o ochronie przyrody. Komentarz, Warszawa 2012.

Radecki W., Ustawa o ochronie zwierzat. Komentarz, Warszawa 2012.

Radwański Z., Prawo cywilne - część ogólna, Warszawa 2009.

Sadowski M., Personalizm chrześcijański Jacques'a Maritain'a jako fundament koncepcji godności człowieka, [w:] Pozytywizm prawniczy i szkoła prawa natury: tradycje sporu i jego wspótczesne implikacje, (red.) P. Kaczmarek i Ł. Machaj, Wrocław 2010. 
Scheler M., Stanowisko człowieka $w$ kosmosie, [w:] Pisma z antropologii filozoficznej i teorii wiedzy, Warszawa 1987.

Singer P., Etyka praktyczna, Warszawa 2003.

Singer P., O życiu i śmierci. Upadek etyki tradycyjnej, Warszawa 1997.

Singer P., Wyzwolenie zwierzat, Warszawa 2004.

Singer P., Zwierzęta i ludzie jako istoty sobie równe, „Etyka” 1980, nr 18. Smaga Ł., Ochrona humanitarna zwierzat, Białystok 2010.

Spaemann R., Osoby. O różnicy miedzy czymś a kimś, Warszawa 2001. Spaemann R., Podstawowe pojęcia moralne, Lublin 2000.

Wroczyński K., O źródłach treści praw człowieka. „Człowiek w kulturze", nr 11.

Wronkowska S., Sytuacje wyznaczane przez normy prawne, [w:] Wronkowska S., Ziembiński Z., Zarys teorii prawa, Poznań 2001.

Tomasz z Akwinu, Suma teologiczna, t. 13, źródło: http://www.katedra.uksw.edu.pl/suma/

suma_indeks.htm.

Zarosa U., Status moralny zwierząt a dwa rodzaje potencjalności, „Etyka praktyczna”, nr 3/2012, źródło: portal www.etykapraktyczna.pl.

Ziembiński Z., Podstawowe problemy prawoznawstwa, Warszawa 1980.

Kontakt e-mail:

dariusz.malinowski2@orange.com 